DOI: 10.46340/eppd.2020.7.6.27

\author{
Zhanna Makeyenko, PhD in Public Administration \\ ORCID ID: https://orcid.org/0000-0003-0188-1906
}

\author{
National academy for public administration under the President \\ of Ukraine
}

\title{
PROFESSIONAL NEGOTIATORS PREPARATION IN PUBLIC ADMINISTRATION
}

\author{
Жанна Макеєнко, к. н. держ.упр. \\ Національна академія державного управління при Президентові України

\section{ПРОФЕСІЙНА ПІДГОТОВЛЕНІСТЬ ПЕРЕГОВІРНИКІВ В ДЕРЖАВНОМУ УПРАВЛІННІ}

\begin{abstract}
The article analyzes the differences between effective and inexperienced negotiators, outlines the general characteristics and skills necessary for achieving negotiator's professional level. Some practical steps to increase the level of professional competence in the system of public administration are offered, and also those that can be provided for in the National academy for public administration under the President of Ukraine. The author pays attention to the factors that affect the training and retraining of negotiators. Practical problems related to the negotiators' activities are considered and possible solutions are suggested. Key issues of training and activities of mediators are also raised. The specific features of this type of negotiator are clarified.
\end{abstract}

Keywords: public administration, conflict, mediation, negotiations, professional training.

Постановка проблеми у загальному вигляді та ї̈ зв'язок з важливими науковими та практичними завданнями. Науковці в області переговорів та переговірники-практики одноголосно погоджуються з тим, що мистецтву ведення переговорів можливо навчитися. Найліпше навчання та/або вдосконалення професійних навичок здійснювати в процесі ведення переговорів, здобуваючи необхідний практичний досвід.

На тематичних курсах і тренінгах, відео-уроках, вебінарах і сайтах в Інтернеті, а також в численній літературі 3 переговорів надається вичерпний перелік порад з успішного ведення переговорів різного рівня, а також засобів впливу на опонента, методів його схиляння до власної точки зору та ін. Описані переговірниками-практиками, траблшутерами (з англ. trouble - проблема, shooter - стрілець, тобто той, хто вирішує проблеми) та медіаторами різноманітні практики та інструменти переговорного процесу можливо застосувати в будь-якій галузі повсякденного життя або діяльності як вдома, так і на роботі. Проте досягнення максимальної ефективності від їх застосування в кожній конкретній ситуації здобувається лише на власному досвіді або із залученням до переговорів досвідчених консультантів-переговірників.

Незважаючи на досить широке висвітлення практичного досвіду ведення переговорів в літературі, все ж основна увага в ній приділена проведенню переговорів в бізнесі, починаючи 3 вирішення повсякденних питань купівлі-продажу i завершуючи проведенням переговорів з організації великомасштабних угод компаній-гігантів. Меншу частину, однак теж добре описану складають міжнародні переговори. I зовсім поверхово представлено переговорний процес в державному управлінні із відображенням окремих його аспектів (наприклад, проведення голосування, врахування різноманітних інтересів та прийняття рішень). При застосуванні переговорів в державному управлінні потрібно враховувати ієрархічність державної системи. Так, переговори на рівні індивідуальної взаємодії між державним службовцем та громадянином, або між державними службовцями по горизонталі будуть значно відрізнятися за рівнем складності, відповідальності та залученості третіх осіб порівняно з переговорами, наприклад, на міждержавному рівні. В будь-якому випадку без постійного застосування в повсякденній діяльності отриманих знань і навичок переговірника, їх ефективність поступово знижується. 
Аналіз останніх публікацій за проблематикою та виділення невирішених раніше частин загальної проблеми. Процесу навчання та виховання лідерських якостей присвячено наукові роботи зарубіжних та вітчизняних дослідників Дж. Кроса, Б. Уейнера, Л. Фестінгера, Г. Спіро, Дж. Спеллера, Дж. Брюнера, К. Роджерса, А. Бандури, Л. Виготської, В. Гошовської ${ }^{1}$, Дж. Мезірова. Теоретичним основам підготовки управлінських кадрів присвячено дослідження українських вчених Н. Бібік, В. Кремень, В. Лугового, В. Майбороди, Б. Олійник, М. Романенко та ін. На важливості професійної компетентності державних управлінців в умовах глобалізації та європеїзації України наголошувалося в працях таких вітчизняних науковців як І. Белебаха, Г. Ващенка, В. Липинського, I. Кресіної, М. Пірен, С. Рудницького та ін.

На сьогодні увітчизняній літературі проблеми навчання та використання навичок переговірника в системі державного управління не знайшли свого комплексного розвитку, що дає підстави говорити про недостатню розробленість даної проблематики в науці «державне управління». Так, комплексний аналіз практичної діяльності успішних переговірників дозволить вивести універсальні принципи, яких дотримуються високоефективні переговірники в практиці ведення переговорів. Ці принципи та методи складуть основу навчального процесу, в якому буде поєднано засвоєння та впровадження практичних кейсів, комп'ютерних симуляцій і персональних тренінгів 3 теоретико-методологічною базою технології переговорного процесу.

Аналіз останніх досліджень та публікацій свідчить про необхідність подальшого вивчення і узагальнення практичного досвіду підготовки та проведення переговорів на різних рівнях системи державного управління. Крім того, питання підготовки кваліфікованих переговірників, орієнтованих на застосування в державному управлінні навиків оволодіння інноваційними технологіями переговорного процесу, й досі залишається актуальним та потребує додаткового висвітлення.

Формулювання цілей (мети) дослідження. В даній статті основну увагу буде приділено професійній підготовленості переговірників в системі державного управління, спираючись на отриманий ними практичний досвід та в поєднанні лідерських якостей управлінців 3 компетенціями медіаторів (переговірників більш широкого спектру використання).

Виклад основних результатів та їх обгрунтування. Аналіз наукових точок зору у відповідній практичній літературі та прикладів ведення переговорів з досвіду кращих переговірників, дає підстави стверджувати, що ефективні переговірники при проведенні переговорів в різних сферах, в тому числі і в державному управлінні, дотримуються певних правил та принципів ведення переговорів. За результатами проведених практичних досліджень переговорного процесу за участі професійних та ординарних переговірників було встановлено ряд відмінностей. В цілому переговірники вкладалися у виділений обсяг часу на підготовку до переговорів, хоча витрачали його по-різному. Так, успішні учасники переговорів набагато більше часу і уваги приділяли стратегічному плануванню переговорного процесу. Ординарні переговірники ж- початковій підготовці, збору даних, їх порівнянню і категоризації, інтерпретації. В результаті чого, на початку переговорів або в їх розпалі, ординарні посередники все ще обмірковували, як найкращим чином використати зібрані дані. Професійні переговірники завжди намагаються розібратися в тому, що приховано за цифрами, а що відбувається в реальності, слідкуючи за розвитком дискусії, вони помічають не лише пропозиції, контрпропозиції та завершальні ходи, а також сприймають глибинні психологічні сигнали, інтерпретують їх для визначення прихованої стратегії опонентів. Прогнозування розвитку подій в довгостроковій перспективі - це саме те, що робить успішний переговірник, те, на що він витрачає вдвічі більший обсяг часу в порівнянні з ординарним переговірником.

Уважність та концентрація на досягненні необхідних результатів переговорів дозволяють вмілим переговірникам безпомилково знаходити потрібний момент для введення пропозиції чи визначати рівень готовності опонента до сприйняття інформації, що дозволить поступово підвести його до потрібних вам висновків чи закріпитися на певних позиціях. Як зазначає Р. Шел у важливих переговорних ситуаціях не слід покладатися на інтуїцію, щоб не помилитися переговірник має бути готовим «відмовитися від упереджень та відкритися для нових ідей» ${ }^{2}$. Не менш важливим навиком для переговірника $є$ розпізнання прихованих психологічних стратегій опонентів в процесі переговорів та обрання контр-стратегій взаємодії. Таким чином, ефективного переговірника від посереднього

\footnotetext{
${ }^{1}$ Гошовська, В. А. (2012). Підвищення рівня професійної компетентності в системі державного управління шлях до формування еліти українського суспільства. Аналітика і влада, 6, 21-25.

$<$ http://nbuv.gov.ua/UJRN/avlad_2012_6_6>. (2020, листопад, 12).

${ }^{2}$ Шелл Р. (2012). Удачные переговоры. Уортонский метод. Москва: Манн, Иванов и Фербер, 16.
} 
відрізняє знання всіх аспектів переговорного процесу та вміння шляхом оцінки поточної переговорної ситуації передбачити подальші дії опонента.

Базовим принципом в цьому випадку виступає довгостроковість взаємовідносин та далекоглядність у плануванні. Зазвичай, переговори не обмежуються однією зустріччю, тож доцільно передбачити серію взаємопов'язаних зустрічей. Для кожної з таких серій зустрічей досвідчений переговірник визначається зі спільною метою переговорів та прояснює конкретну мету окремої зустрічі; спектр питань, що підлягають обговоренню на кожній зустрічі та їх пріоритизацію в дискусії. За кожним з переліку спірних питань на переговорах він підготує та розгляне по п'ять і більше можливих варіантів їх вирішення, в той час як ординарний переговірник обмежиться розглядом від одного до трьох варіантів. Окремо потрібно звернути увагу на повноваження переговірника, надані йому як представнику і виразнику групових інтересів делегації (сторони), що дозволяють йому самостійно вирішувати наскільки глибокого пропрацювання та розгляду потребує те чи інше питання, змінювати регламент переговорів наскільки це буде необхідно з точки зору потреб подальшого впровадження досягнутих результатів.

Набуті знання та відточені практичні навички дозволяють ефективному переговірнику грамотно вибудовувати переговори та почуватися більш упевненим в своїх діях в будь-якій ситуації. Отже, з точки зору досвіду проведення переговорів ефективний та досвідчений переговірник підходить до виконання своїх функцій на переговорах у наступний спосіб:

1) налаштовуючи комунікаційні зв'язки, наприклад, домагається використання однаково зрозумілої учасникам переговорів специфічної термінології, мови для продуктивного спілкування;

2) розставляючи необхідні акценти у пошуку спільних інтересів учасників переговорів;

3) розглядаючи різні джерела інформації для збору необхідних даних;

4) здійснюючи перевірку досягнутого порозуміння між сторонами та підбиття підсумків за кожним питанням, обговорення якого завершено;

5) моніторячи власні поведінкові реакції та поведінку інших представників сторін;

6) виявляючи та детермінуючи спроби маніпуляцій, непередбачуваних змін в перебігу переговорного процесу, так звані подразники, що спонукають протилежну сторону до негайного реагування;

7) майстерно переконуючи протилежну сторону в переговорах до прийняття пропозиції на його умовах та ін.

Перші кроки досвідчені переговірники роблять ще на стадії планування майбутніх переговорів в частині дослідження загальних інтересів, витрачаючи на це втричі більше часу, ніж витратили б посередні переговірники. Детально розглянувши суть проблеми переговорів досвідчені переговірники паралельно починають вирішувати проблему ефективного спілкування, що постає перед учасниками переговорів. Особливо, якщо це міжнародні переговори з представниками іншої раси з відмінними традиціями та культурою. Найчастіше на шляху до ефективного спілкування досвідчені переговірники допомагають усуненню наступних перепон:

- мовленнєві особливості спілкування однієї сторони часто бувають незрозумілі іншим сторонам переговорів. Причинами цього можуть бути двозначність тлумачення окремих термінів, що набули іншого змістовного забарвлення під впливом етнічних особливостей. Або, наприклад, представники цієї сторони через використання специфічної незрозумілої термінології намагаються справити певне враження на іншу сторону чи піймати переговірника у пастку невірного тлумачення проголошених потреб цієї сторони;

- сторони не звертають уваги на слова промовця на переговорах, тож спілкування як таке між сторонами не відбувається. Така ситуація зазвичай складається на початку етапу ведення переговорів, коли представники сторін продовжують розмірковувати над результатами виконання підготовчої стадії. Також усвідомлена відмова сторін сприймати інформацію від протилежної сторони є сигналом до розгортання конфлікту і потреби в короткій перерві в дискусії, дебатах;

- кожна сторона вкладає власний зміст в проголошені слова, таким чином порушуючи комунікативну рівновагу в переговорному процесі. Цього можливо уникнути, якщо досвідчений переговірник візьме на себе зобов'язання повторювати сказане іншими словами, ставлячи уточнюючі питання для розкриття змісту сказаного. Крім того, у випадку розгортання конфлікту, така стратегія дозволяє перевести комунікацію між сторонами з яскраво вираженої конфліктної до нормального робочого спілкування. В цьому незамінним помічником ефективного переговірника $\epsilon$ «активне слухання», що полягає в мистецтві розуміння сказаного співрозмовником, в процесі розшифрування 
сенсу мовленнєвих повідомлень, з'ясування реального їх значення.

Результатом належного врахування сторонами комунікативного компоненту $є$ перехід до наступної фази - аналізу прихованих інтересів сторін. Проголошені учасниками переговорів позиції, зазвичай, приховують їх реальні інтереси та потреби. На підтвердження цього Р. Шел зазначає, що «переговори - процес двосторонньої комунікації, який може розгорнутися, коли ви чогось потребуєте від іншої людини або інша людина потребує чогось від вас» ${ }^{1}$. Як показують результати дослідників Гарвардського методу ведення переговорів робота на рівні інтересів, а не позицій $\epsilon$ набагато ефективнішою: по-перше, задоволення кожного окремого інтересу сторони можливе з кількох позицій, що відразу збільшує число можливих варіантів; по-друге, навіть в протилежних позиціях $\epsilon$ можливість віднайти більше співпадаючих інтересів сторін, ніж в позиціях, які увійшли в безпосереднє протиріччя. Ступінь задоволення інтересів сторін напряму залежить від коректного їх формулювання та донесення інформації про їх важливість до відома інших сторін.

Прояснення позиції та інтересів учасників переговорного процесу неможливе без запитань. Практичні дослідження показали, що успішні переговірники на $21,3 \%$ частіше використовують поведінку, спрямовану на задоволення інформаційного «голоду», проти 9,6\% своїх ординарних колег ${ }^{2}$. Таким чином ставлення досвідченими переговірниками запитань на певних етапах ведення переговорів було націлено на:

- перевірку раніше зроблених припущень, зазвичай під час планування;

- управління фокусом обговорення питання;

- «розрядку» емоційну або ситуації, в умовах виникнення (силового/психологічного) тиску і напруги у відносинах сторін;

- заміну прямої незгоди щодо якогось питання більш прийнятною альтернативою;

- пошуки, дослідження загальних інтересів сторін і підсилення в них спільного / відмінностей 3 метою вироблення більшого числа варіантів.

Освоєння навичок роботи з питаннями на практиці дозволяє не лише правильно формулювати питання, але й відчувати необхідний момент, коли їх проголошення дійсно змінить перебіг процесу переговорів або ж результати взаємодії між сторонами. Іншим наслідком освоєння вміння «ставити запитання» $є$ потреба в моніторингу власного розуміння ситуації, що склалася на переговорах, шляхом постійної перевірки та оцінки якості зроблених припущень. Відомий експерт в області переговорів Р. Шел акцентує увагу на важливості розвитку цього навику, зокрема, він наголошує: «спочатку намагайтеся зрозуміти, потім - щоб вас зрозуміли» ${ }^{3}$. Факти, отримані в результаті досліджень поведінки учасників переговорів під час навчальних сесій, підтверджують, що в середньому досвідчені переговірники більше ніж на $17 \%$ зверталися до вище зазначених умінь, в той час як ординарні переговірники - менше $8 \%$, тобто майже в два рази менше 4 .

Варто зазначити, що справжня різниця між досвідченими та ординарними переговірниками, як правило, проявляється наприкінці переговорів. У той час як ординарні переговірники прагнуть якомога швидше досягти угоди і завершити переговори, побоюючись додаткової напруженості у відносинах чи відкритої незгоди іншої сторони. Вмілі та досвідчені переговірники завжди прагнуть налагодити тісний взаємозв'язок між досягнутими домовленостями та їх успішною реалізацією. Адже навмисна неуважність до глибокого «зондування» потенційних областей неправильного розуміння чи двозначного тлумачення, може не лише затягнути підписання майбутньої угоди, але й спровокувати появу ускладнень на етапі ії впровадження чи виконання зобов'язань сторонами.

Ефективний переговірник не шкодуватиме часу на перевірку та «резюмування» переговорів, оскільки це дозволить скласти повне уявлення про інтереси та потреби сторін, зважаючи на особливості переговорної ситуації. Ці на перший погляд «втрати» обернуться для нього нагородою по завершенню переговорів у вигляді мінімізації потенційних ризиків на стадії впровадження вимог досягнутої угоди. Досвід успішного проведених результативних переговорів надає переговірнику певний рівень довіри та статус професіонала в своїй діяльності. При виборі переговірника саме ці фактори в кінцевому підсумку впливають на прийняття остаточного рішення сторонами.

\footnotetext{
${ }^{1}$ Шелл Р. (2012). Удачные переговоры. Уортонский метод. Москва: Манн, Иванов и Фербер, 21.

${ }^{2}$ Harvard Business Review (2020). Homepage <http://hbr-russia.ru/>. (2020, листопад, 12).

${ }^{3}$ Шелл Р. (2012). Удачные переговоры. Уортонский метод. Москва: Манн, Иванов и Фербер, 9.

${ }^{4}$ Harvard Business Review (2020). Homepage <http://hbr-russia.ru/>. (2020, листопад, 12).
} 
Окреслені нами правила поведінки ефективних переговірників слід віднести до категорії знань та вмінь, які можливо розвити в собі самостійно або за допомогою кількаденних навчальних тренінгів, семінарів, і в такий спосіб істотно покращити власні переговорні здібності. Однак, потрібно усвідомлювати, що психологічні механізми, які забезпечують нам послідовний рух до наміченого результату ${ }^{1}$, по-різному впливають на нашу поведінку. В ситуації, коли переговори вже почалися, перед переговірником постає важке завдання в стислі терміни пізнати і відчути свого опонента, щоб в подальшому схилити його до своєї точки зору. При цьому потрібно розуміти і весь час пам'ятати, що протилежна сторона намагається досягти того ж в переговорах, а тому переговірник буде змушений протистояти їі методам.

Велике значення для оцінки ефективності переговірника має усвідомлення ним власної поведінки та готовність / здатність іiі змінювати в ході переговорів (переговорна гнучкість). Досвідчені переговірники виявляють загальну схильність до уникнення певних поведінкових категорій в ході переговорів, а при ідентифікації ознак такої поведінки в інших учасників переговорного процесу здійснюють оперативні дії щодо зменшення загального деструктивного ефекту на атмосферу переговорів. Під час конфлікту учасники переговорів схильні проявляти сильні емоції та висловлювати оціночні судження. На певному етапі розгортання конфлікту, така поведінка формує тенденцію до спірально-наростаючої інтенсивності конфліктних відносин. В результаті нападки сторін стануть ще запекліші та завзятіші, а спіраль буде набирати нових обертів. Сторонам буде важко самостійно розібратися де законна оборона, а де невиправдана атака, оскільки їх відчуття реальності переговорної ситуації притуплені емоціями.

Вмілі та досвідчені переговірники, розпізнавши перші ознаки спіралі конфлікту, якщо приймають рішення про необхідність нападу, то роблять це жорстко і без жодних попереджень усвідомлено, швидко і впевнено, без зайвих емоцій. Ординарні переговорники навпаки особливо схильні використовувати в якості захисту фрази, що замість приглушення часто провокують наростання гострих реакцій іншої сторони. Практика свідчить, що ординарні переговірники в тричі частіше потрапляють до пасток поведінкової спіралі, ніж їх досвідчені колеги.

До іншої категорії неконструктивної поведінки відносять роздратування, що є реакцією на різні види подразників вербального чи невербального направлення. Вербальні подразники - це слова або фрази, які в контексті переговорної ситуації особливо дратують, «зачіпають за живе» протилежну сторону тому що, як правило, не відповідають дійсності. Візуально невербальні подразники проявляються через міміку обличчя (наприклад, підняття брів у виразі щирого здивування, поблажлива посмішка та ін.) та рухи тіла, жести рук, що відображають різку зміну настрою як реакцію на сказане опонентом. Якщо протилежна сторона своїм зауваженням випадково (або ні) поставила під сумнів статус опонента або імідж організації, яку він представляє, то реакція на ці подразники може мати стрімкий та вибуховий ефект. В інших учасників переговорів така поведінка викликає щире здивування і зазвичай, розцінюється як прояв «ірраціональності» людської поведінки. Для пояснення цього факту доцільно навести слова Р. Шела про те, що «мистецтво (переконувати) відшліфовується кожного разу, коли ви знаходите баланс між, з одного боку, власними інтересами, авторитетом, точкою зору і рівнем відповідальності а, з іншого боку, потребами, сприйняттям і відчуттями аудиторії, яку необхідно переконати»².

Практика показує, що на навчальних сесіях цей навик є одним з найбільш складних для освоєння переговірниками. При чому, ординарні переговірники схильні звинувачувати інших учасників навчального семінару, тренінгу в неприпустимості такої поведінки по відношенню до них, а тренера в упередженості. У той час як досвідчені та вмілі переговорники абсолютно реалістично оцінюють власний внесок в переговори, визнають факти, що мали місце в процесі обговорення спірного питання i, в разі визнання такої поведінки неефективною, виключають іiі зі свого арсеналу продуктивних інструментів. Таким чином, ми можемо зробити важливий висновок щодо важливості давати собі об’єктивний зворотний зв'язок з приводу власної поведінки в процесі ведення переговорів.

Так само як рівень IQ є виразником рівня звичайного раціонального інтелекту, рівень EQ (Emotional Quotient з англ. емоційного фактору) визначає здатність до усвідомленої регуляції й управління як власними емоціями, так і емоціями інших людей. Таку здатність часто називають «емоційною компетентністю» або «емоційним інтелектом» (ЕІ з англ. Emotional Intelligence). Даним

\footnotetext{
${ }^{1}$ Климов, Е. А. (1982). Индивидуальный стиль деятельности Психология индивидуальных различий. Москва: МГУ, 40.

2 Шелл Р. (2012). Удачные переговорыл. Уортонский метод. Москва: Манн, Иванов и Фербер, 9.
} 
терміном з 1990 р. науковці (Р.К. Купер, А. Саваф, Дж. Мейер, П. Селовей, Д. Карузо, Д. Гоулман, Т. Бредбері, Дж. Грівз, М. Кетс де вріс, Р. Бар-Он, С. Стейн, Г. Бук, Р. Бояцис, Х. Ріндерман та ін.) почали описувати групу ментальних здібностей, що сприяють усвідомленню і розумінню власних емоцій та емоцій оточуючих. Дослідники Т. Бредбері та Дж. Грівз особливо наголошували на невіддільності понять емоційного та раціонального інтелекту; «інтенсивний потік інформаційного обміну між раціональним та емоційним центрами мозку»; «об'єднання раціонального мислення та емоційних реакцій» ${ }^{1}$.

Учасник переговорів з низьким рівнем EQ не досягає успіху в переговорах з наступних причин:

1. Не вміє вчасно розпізнати власні почуття та недостатньо повно розуміє причини, що спонукають його до тих чи інших дій;

2. Погано розуміється і розпізнає почуття та психологічний стан своїх партнерів. Не відчуває їх настрій, бажання, інтереси або тривоги;

3. Не вміє керувати власним емоційним станом, через що дозволяє емоціям керувати ним. Не знає як налаштовувати себе на необхідну хвилю, швидко відновлюватися після невдач;

4. Не може створити довірчі відносини з партнером, передати інтерес і надихнути партнера на прийняття рішення. Не може підтримувати робочі відносини в довгостроковій перспективі.

На думку Д. Гоулмана «умовою високого розвитку емоційного інтелекту повинні виступити достатні показники загального інтелекту на тлі розвиненої емоційної сфери» ${ }^{2}$. Іншими словами ЕI означає вміння керувати своїми почуттями таким чином, щоб висловлювати їх в потрібний момент i 3 користю, сприяючи таким чином досягненню загальних цілей.

У зв'язку з чим не можливо оминути увагою питання «харизми», дослідження якого останнім часом набуло широкої популярності. Наукові розробки цього явища доводять, що харизматичний вплив може бути керованим, і поповнити «арсенал» навичок сучасного лідера. Ефект харизми фактично полягає в тому, щоб націлити всі свої здібності та вміння на забезпечення емоційного та інтелектуального впливу на оточуючих, тобто впливаючи на їх думки, ставлення і поведінку справити на них сильне, незабутнє враження. Провідний світовий експерт в області харизми - Олівія Фокс Кабейн в своїй книзі «Харизма. Як впливати, переконувати та надихати» ${ }^{3}$ доводить, що харизма - це навичка, яку можливо розвинути за допомогою практичних вправ, спрямованих на підвищення рівня самосвідомості та навчання застосуванню різних аспектів ефекту харизми. Таким чином, слід очікувати, що харизма як ефективний інструмент в руках державного управлінця, багаторазово підсилить його вплив на окремих осіб (вищого, нижчого або рівного з ним рангу) чи групу людей, сприятиме результативним досягненням, надаватиме можливість швидко перегрупуватися та відновити сили у випадку невдачі в переговорах або іншій діяльності.

Позитивним ефектом від опанування секретів «харизми» $\epsilon$ підвищення якості публічних виступів та відповідне зниження рівня стресу, пов'язаного з цим. Публічний виступ в державному управлінні $є$ неодмінною умовою високого рейтингу держслужбовця як політика і $є$ одним із способів провести переговори з великою за обсягом аудиторією. Серед основних споріднених з переговорами порад, в контексті професійної підготовки держслужбовця, слід виділити наступні: 1) спорідненість вербального і невербального під час виступу, оскільки дисонанс тону мови та «мови» тіла може викликати недовіру та втрату інтересу в аудиторії; 2) управління власними емоціями під час виступу та підкорення ірраціональних страхів завдяки попередній психологічній установці; 3) комунікативна складова, налаштованість на якнайкраще донесення суті виступу та отримання відгуків від аудиторії; 4) формування позитивного враження від виступу та оратора через подання оратором власної персони 3 акцентом на доброзичливість, почуття гумору та «людини з народу», яка розуміє ваші проблеми.

Резюмуючи вище викладене потрібно по-новому сформувати вимоги до поведінки та професійних якостей переговірника. В сучасних умовах розвитку державного управління, тенденцій до формування управлінської еліти та активного пропагування підготовки і перепідготовки державних службовців з метою їх адаптації до стандартів Європейського союзу оцінка професіоналізму переговірників здійснюється, виходячи з:

I. Принципів регулятивності та цілеспрямованості. В сучасних умовах українське суспільство пред’являє більш високі норми поведінки, що логічно розповсюджується і на кодекс професійної етики переговірників.

\footnotetext{
${ }^{1}$ Бредбери, Т., Гривз, Дж. (2009). Эмоцииональный интеллект 2.0. Москва: Манн, Иванов и Фербер, 28.

${ }^{2}$ Гоулман, Д. (2009). Эмоичональный интеллект. Москва; Владимир: АСТ; ВКТ, 74.

${ }^{3}$ Кабейн, О. Ф. (2013). Харизма. Как влиять, убеждать и вдохновлять. Москва: Альпина Паблишер, 307.
} 
II. Потреби захищати суспільні інтереси та інтереси держави, узгоджуючи їх в керівному спрямуванні при провадженні державної політики. Якщо ж суспільство не отримує вигоди від автономної діяльності державних службовців, наприклад депутатів їх потрібно позбавити цього привілею.

III. Необхідності уникнення двозначностей та пропагування чесності. В даному випадку кодекс переговірника надаватиме додаткових обмежень діям державних службовців, особливо в частині уникнення специфічних спокус, які можуть відчувати посадовці в системі державного управління. Визнання темних, неетичних сторін професії держслужбовця та їх повноцінне відображення в кодексі $€$ передумовою до закладення в ньому чітко визначеної системи лімітів та контролів.

IV. Об'єктивної необхідності бути контрольованим і контролюючим. Прозорість складення положень кодексу є потужним стимулом для держслужбовця до самоконтролю, контролю діяльності інших з метою уникнення специфічних помилок, недоліків їх професії. Наявність в кодексі положень про пред'явлення звинувачень і застосування покарань дає суспільству підстави для встановлення кредиту довіри державним посадовцям, а у випадку виправдання такої довіри - додаткових привілеїв. У такий спосіб суспільство здійснює контроль над діяльністю виборних представників в системі державного управління та впливає на законотворчу діяльність ${ }^{1}$.

Аналіз сучасного стану професійного навчання, підготовки та перепідготовки державних службовців дає підстави відзначити позитивні тенденції в його реформації, а саме відходу від інформативного та академічного характеру системи навчання в бік більш практичного їі спрямування, що відповідає потребам динамічного розвитку держосвіти та розширенню набору навичок, необхідних для виконання службових обов'язків. Такі види навчання як: навчання за магістерськими програмами; навчання за професійними програмами підвищення кваліфікації державних службовців; самостійне навчання (самоосвіта), зокрема участь у щорічному Всеукраїнському конкурсі „Кращий державний службовець”; тематичні постійно діючі семінари; тематичні короткотермінові семінари, зокрема тренінги; стажування в органах, на які поширюється дія Закону „Про державну службу”, а також за кордоном, частково компенсують недостатній теоретичний рівень знань і практичних умінь працівників державних органів. Однак динаміка показників за різними формами професійного навчання підтверджує недостатність удержавно-управлінських кадрів знань та вмінь 3 питань стратегічного планування, проектного менеджменту, прийняття управлінських рішень, публічної діяльності ведення ефективної інформаційної роботи, переговорів, взаємодії з громадськістю тощо.

Звичні для України форми навчання, що продовжують використовуватися у вищих навчальних закладах, доповнюються мобільними формами професійного навчання, що в цілому сприяє оперативному наданню необхідних знань та більш масштабному охопленню різних категорій державних службовців. Так, Національна академія державного управління при Президентові України, заручившись підтримкою найкращих кадрів вітчизняних наукових шкіл, представників міжнародних організацій провадить численні проекти, наприклад, спільно з Університетом Гамбургу щодо «Створення Бюро медіації і навчання медіаторів», USAID за програмою «Лідерство в економічному врядуванні» (ЛЕВ), асоціацією «l'Ukraine dans l'Europe» в частині «Підвищення кваліфікації державних службовців у сфері європейської інтеграції та державного управління», із запровадження «Міжнародного досвіду публічного адміністрування для України» та багато інших 2 .

Міжнародний досвід, зокрема, Німеччини, Франції, Польщі, Нідерландів, Канади та США, який активно впроваджується в українську навчальну систему, також свідчить на користь залучення позаштатних лекторів-практиків для викладання у школах державного управління, в першу чергу розрахованих на задоволення потреб вищого корпусу державної служби. Крім того, широкої практики в системі підготовки та перепідготовки професіоналів набули тенденції до поглиблення індивідуалізації й практичної орієнтації навчальних програм. Також, за підтримки міжнародних організацій і в рамках провадження програм TWINNING, TAIEX ${ }^{3}$ та інших, в Україні проводяться сучасні семінари-тренінги з питань налагодження комунікацій, стратегічного планування та молодіжної, соціальної і публічної політики Європейського Союзу.

\footnotetext{
${ }^{1}$ Подопригора, М. Г. (2012). Деловая этика. Учебное пособие. Таганрог: ТТИ ЮФУ, 116.

${ }^{2}$ Національна Академія Державного Управління при Президентові України (2020). Міжнародні проекти $<$ http://academy.gov.ua/?lang=ukr\&tip=dop\&tipn=Page\&page=34>. (2020, листопад, 12).

${ }^{3}$ Національне агентство України з питань державної служби (2020). Головна сторінка $<\mathrm{http}: / /$ nads.gov.ua/news $>$. (2020, листопад, 12). SIGMA (2020). Головна сторінка <http://www.sigmaweb.org/>. (2020, листопад, 12)
} 
Інститут підвищення кваліфікації керівних кадрів Національної академії державного управління при Президентові України, на правах єдиного навчально-методичного закладу системи підвищення кваліфікації в Україні забезпечує практичну модернізацію навчання в частині підвищення кваліфікації керівників закладів системи підготовки, перепідготовки та підвищення кваліфікації держслужбовців і посадових осіб місцевого самоврядування. У відповідності до основоположних напрямків реформування системи навчання, визначених Законом України «Про державну службу» від 17 листопада 2011 р., даний навчальний заклад має необхідний потенціал для ефективного задоволення потреб системи державного управління в кваліфікованих кадрах, його викладачі відрізняються прогресивністю поглядів та оперативним реагуванням на вимоги часу ${ }^{1}$. При цьому головним орієнтиром для підвищення професійного рівня і компетентності управлінських кадрів, які реалізують функції держави, залишається активне запровадження інноваційних технологій та здобутків світового досвіду переговорної діяльності.

На сьогодні в рамках проходження проекту по створенню Бюро медіації і навчання медіаторів в Національній академії державного управління при Президентові України та за нормативно-правової підтримки (в червні 2016 року у Верховній раді було зареєстровано два проекти закону про медіацію) активно розробляються програми з підготовки професійних медіаторів в сфері державного управління. Враховуючи специфіку державної роботи, медіація може виявитися досить ефективною в ряді випадків (знеособлене спілкування сторін, підтримання конфіденційності тощо), а в інших єдиним можливим варіантом узгодження інтересів сторін. Згадуваний вище проект розрахований на системне навчання медіації та практичне надання такого виду послуг в системі державного управління, досягнення головної мети, яка ставиться перед медіатором, - допомогти знайти сторонам додану цінність в переговорах, а також знайти рішення, які були б оптимальними для всіх сторін переговорів з урахуванням інтересів сторін (включаючи психологічні). Медіація в порівнянні з будьякою моделлю переговорів характеризується чітким алгоритмом послідовних дій, яких медіатор повинен дотримуватися для упорядкування процесу пошуку рішення. Тому одним із найважливіших моментів реалізації проекту є адаптація положень Кодексу медіатора (визнаного в Свропі та світі) для використання українськими фахівцями.

Формування у державних посадовців культури медіації $\epsilon$ комплексним інтегрованим процесом, що перебуває в ситуації перманентного розвитку і вимагає глибоко продуманої координації технологічного та дидактичного забезпечення психолого педагогічної й професійної підготовки таких фахівців в державному управлінні. Співвідношення та складові культури медіації показано на рис. 1 :

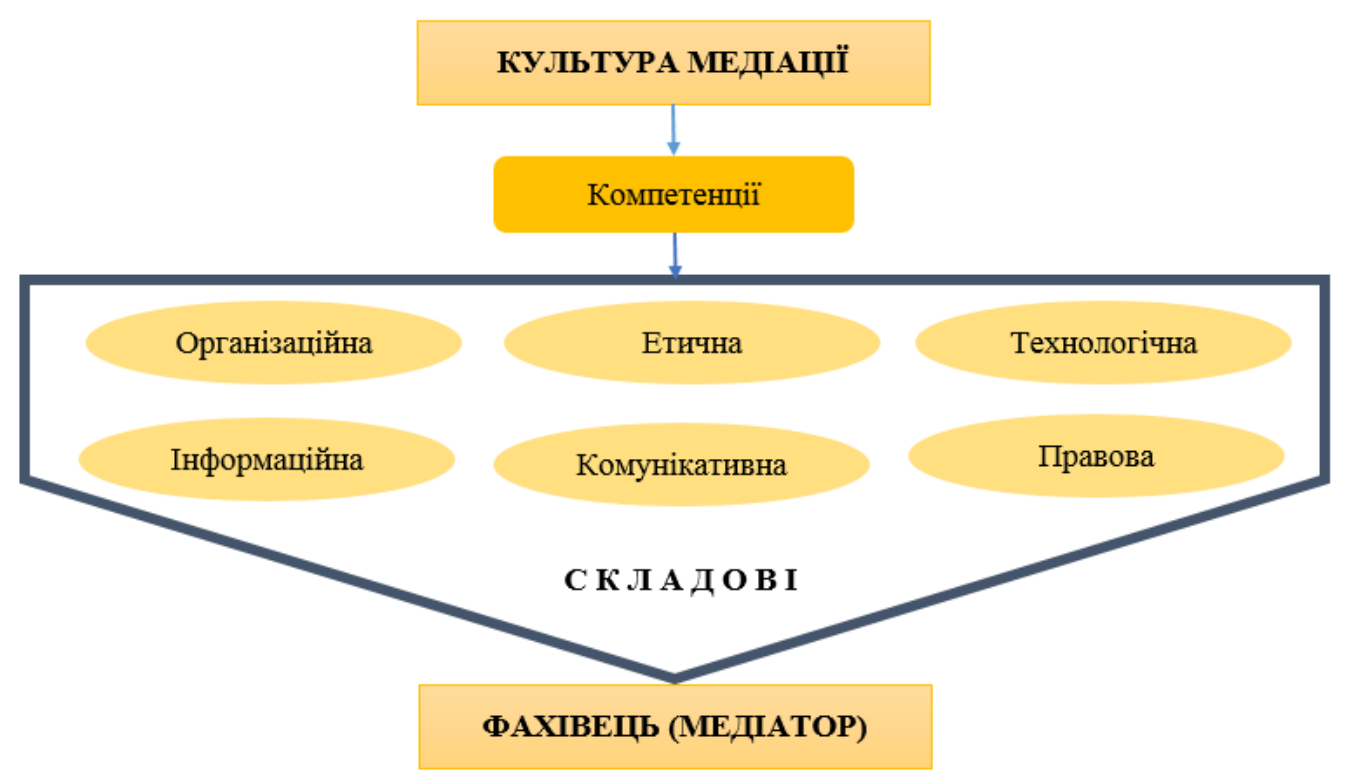

Рис. 1. Структура культури медіації фахівця - медіатора

\footnotetext{
${ }^{1}$ Гошовська, В. А. (2012). Підвищення рівня професійної компетентності в системі державного управління шлях до формування еліти українського суспільства. Аналітика $і$ влада, 6, 23 $<$ http://nbuv.gov.ua/UJRN/avlad_2012_6_6>. (2020, листопад, 12).
} 
Як зрозуміло зі схеми кожна складова (компетенція) культури медіації передбачає наявність сукупності знань, умінь і навичок, необхідних для здійснення процесу медіації. Крім того, культура медіації передбачає володіння навичками міжособистісної діалогової рівноправної суб'єкт-суб'єктної комунікативної взаємодії․․ Таким чином культивування кращих технологій проведення медіації в поєднанні з розвитком і пропагуванням культури медіації в цілому сприятиме підвищенню професійних навичок переговірника серед державних службовців.

Висновки та перспективи подальших досліджень. На прикладі активного впровадження новітніх технологій та реалізації спільних проектів викладачам Національної академії державного управління при Президентові України вдається забезпечувати високий рівень професійної компетентності управлінських кадрів протягом їх професійної діяльності, оперативність прийняття управлінських рішень, передачу кращого управлінського досвіду, методів та прийомів державного управління, в тому числі, стимулювання державних службовців до свідомої самоосвіти в галузі їхньої професійної діяльності.

Перспективи подальших досліджень вбачаємо в реалізації наступних пропозиції з покращення професійної підготовки державних службовців в якості переговірників (медіаторів) або їх перепідготовки в сучасних вищих навчальних закладах:

- затвердженні та поетапній реалізації впровадження інноваційних технологій переговорів в систему навчання на прикладі Національної академії державного управління при Президентові України та подальша їі диверсифікація на інші вищі навчальні заклади, що обслуговують та постачають кваліфіковані кадри до органів державного управління.

- розробці кількох типів нових навчальних програм та використання інноваційних технологій в навчальному процесі, що забезпечуватимуть різний рівень навчання для спеціальної підготовки фахівців-переговірників або посередників в галузі державного управління; перепідготовку фахівців, що мають вищу освіту, й надання їм кваліфікації переговірника в цій галузі; на постійній основі підвищення кваліфікації фахівців в системі державного управління; заохочення їх до самонавчання та саморозвитку.

- законодавчій підтримці щодо формування належної нормативно-правової бази, яка регламентуватиме всі процеси з формування та навчання кваліфікованих кадрів в системі державного управління.

- посиленні інфраструктури, яка забезпечує освітній процес державних службовців, а також системи навчально-методичного забезпечення всіх форм навчання;

- вивченні і прикладному застосуванні міжнародного досвіду з проблем професіоналізації державної служби, в тому числі щодо організації безперервної освіти державних службовців, та використання цієї практики в Україні.

\section{References:}

1. Hoshovska, V. A. (2012). Pidvyshchennya rivnya profesiynoyi kompetentnosti v systemi derzhavnoho upravlinnya shlyakh do formuvannya elity ukrayinskoho suspilstva [Increasing the level of professional competence in the system of public administration is a way to form the elite of Ukrainian society]. Analityka $i$ vlada [Analytics and power], 6, 21-25. 〈http://nbuv.gov.ua/UJRN/avlad_2012_6_6>. (2020, November, 12). [in Ukrainian].

2. Shell R. (2012). Udachnyye peregovory. Uortonskiy metod [Successful negotiations. The Wharton Method]. Moscow: Mann, Ivanov i Ferber. [in Russian].

3. Harvard Business Review (2020). Homepage <http://hbr-russia.ru/>. (2020, November, 12). [in English].

4. Klimov, E. A. (1982). Individualnyy stil deyatelnosti Psikhologiya individualnykh razlichiy [Individual style of activity Psychology of individual differences]. Moscow: MSU. [in Russian].

5. Bradbury, T., Greaves, J. (2009). Emotsionalnyy intellekt 2.0 [Emotional Intelligence 2.0]. Moscow: Mann, Ivanov i Ferber. [in Russian].

6. Goleman, D. (2009). Emotsionalnyy intellekt [Emotional intellect]. Moscow; Vladimir: ACT; VKT. [in Russian].

7. Kabeyn, G. F. (2013). Kak vliyat, ubezhdat $i$ vdokhnovlyat [Charisma. How to influence, convince and inspire]. Moscow: Alpina Publisher. [in Russian].

8. Podoprigora, M. G. (2012). Delovaya etika. Uchebnoye posobiye [Business ethics. Tutorial]. Taganrog: TTI SFU. [in Russian].

\footnotetext{
${ }^{1}$ Мета, Г., Похмелкина, Г. (2004). Медиация - искусство разрешать конфликты. Знакомство с теорией, методом и профессиональными технологиями. Москва: Verte, 86.
} 
9. Natsionalne ahentstvo Ukrayiny z pytan derzhavnoyi sluzhby (2020) [National Agency of Ukraine for Civil Service Affairs (2020)]. Holovna storinka [Main page] <http://nads.gov.ua/news>. (2020, November, 12). [in Ukrainian].

10. SIGMA (2020). Holovna storinka [Main page] <http://www.sigmaweb.org/>. (2020, November, 12). [in Ukrainian].

11. Natsionalna Akademiya Derzhavnoho Upravlinnya pry Prezydentovi Ukrayiny (2020) [National Academy of Public Administration under the President of Ukraine (2020)]. Mizhnarodni proekty [International projects] <http://academy.gov.ua/?lang=ukr\&tip=dop\&tipn=Page\&page=34>. (2020, November, 12). [in Ukrainian].

12. Meta, G., Pokhmelkina, G. (2004). Mediatsiya - iskusstvo razreshat konflikty. Znakomstvo s teoriyey, metodom i professionalnymi tekhnologiyami [Mediation is the art of resolving conflicts. Acquaintance with theory, method and professional technologies]. Moscow: Verte. [in Russian]. 